\title{
Phytoremediation of Nickel, Lead and Manganese in Simulated Waste Water Using Algae, Water Hyacint and Water Lettuce
}

\author{
Sani Nasiru Alhaji ${ }^{1,}$, , Sulaiman Asmau Umar ${ }^{2}$, Sokoto Muhammad Abdullahi ${ }^{2}$, Shehu Kasimu ${ }^{3}$, \\ Salisu Aliyu ${ }^{1}$ \\ ${ }^{1}$ Department of Chemistry, Federal University Gusau, Gusau, Nigeria \\ ${ }^{2}$ Department Pure and Applied Chemistry, Usmanu Danfodiyo University, Sokoto, Nigeria \\ ${ }^{3}$ Department Biological Sciences, Usmanu Danfodiyo University, Sokoto, Nigeria
}

Email address:

nasirualhajisani@yahoo.com (S. N. Alhaji)

${ }^{*}$ Corresponding author

\section{To cite this article:}

Sani Nasiru Alhaji, Sulaiman Asmau Umar, Sokoto Muhammad Abdullahi, Shehu Kasimu, Salisu Aliyu. Phytoremediation of Nickel, Lead and Manganese in Simulated Waste Water Using Algae, Water Hyacint and Water Lettuce. International Journal of Mineral Processing and Extractive Metallurgy. Vol. 5, No. 2, 2020, pp. 30-36. doi: 10.11648/j.ijmpem.20200502.12

Received: July 14, 2020; Accepted: August 4, 2020; Published: August 13, 2020

\begin{abstract}
The increase in industrial and artisanal mining and mineral processing activities has led to a surge in the quantity of hazardous materials, typically heavy metals that are released into the environment. These hazard materials, when discharge in water bodies, poses serious risk to humans, animals and environment. Phytoremediation is one of the cost effective methods use in the removal of these pollutants from environment. Several plants have been investigated for their phytoremediating potentials. In this paper, the phytoremediation potential of algae, water hyacinth and water lettuce for the removal of $\mathrm{Ni}$, $\mathrm{Pb}$, and $\mathrm{Mn}$ was demonstrated. Plants of equal size were grown in aqueous medium and supplemented with different concentration $\left(1.0 \mathrm{mg} / \mathrm{dm}^{3}, 3.0 \mathrm{mg} / \mathrm{dm}^{3}\right.$ and $\left.5.0 \mathrm{mg} / \mathrm{dm}^{3}\right)$ of multi component metal solution for 15 consecutive days. All the plants revealed a very good accumulation potential, with the accumulation of metals shown to increase with an increase in the initial concentration of the metal solution. At all levels, the plants accumulated the metals more in the root than in shoot except for $\mathrm{Mn}$ in water hyacinth. The result showed that water hyacinth was able to accumulate $\mathrm{Pb}$ better, while water lettuce showed more preference for $\mathrm{Ni}$ and $\mathrm{Mn}$. All the three plants can be used in remediating waste water. Hence, water hyacinth, water lettuce and algae are a promising biomass for phytoremediation.
\end{abstract}

Keywords: Phytoremediation, Algae, Water Hyacinth, Water Lettuce, Heavy Metals

\section{Introduction}

Pollution of the aquatic environment by heavy metals is one of the major threats to the water resources of the world today. Heavy metals pollutants are of concern due to the nondegradability hazard they creates (under natural conditions) when discharged into a water body and the serious health complications attributed to them [1-3]. The 1956 Minamata disease caused by mercury contamination on fish is a good example. The disease claimed the lives of nearly 900 people in Japan and more than 2 million were reported to have suffered from different health complications.
Contamination of aquatic environment can therefore be linked to the increase in the anthropogenic activities (ore mining, oil exploration, industrial effluents), which led to generation of tonnes of wastes into aquatic environment, soil, or emitted into the air [4]. The contamination of aquatic ecosystems by heavy metals may also result from weathering of soil and rocks from volcanic eruptions [5], or from natural soils due to the changes in local redox conditions and the corrosion of subsurface engineering structures due to prolonged submergence under acidic groundwater. Okafor et al, (2007) and Mohiuddin, et al, (2010) reported that, trace elements may be immobilised within the stream sediments and thus could be involved in absorption, co-precipitation, 
and complex formation $[6,7]$.

To avert the environmental effect caused by heavy metal pollution, several conventional techniques such as reverse osmosis, ion exchange, chemical precipitation, electrochemical treatment, reverse osmosis, adsorption, electro dialysis etc were reported [8-10]. However, these so called conventional methods are quite costly, energy intensive and metal specific. Therefore, there exists a definite need to develop a low cost, eco-friendly and sustainable technology to serve as substitute to the conventional methods already reported [11].

Thanks to Biotic remediation, it is an eco-friendly, cost effective and promising technology that uses plants to remediate/remove heavy metal from waste water [12]. Rhizofiltration is the most common biotic remediation process that is utilized to absorb and concentrate contaminants from polluted aqueous sources in their roots [13]. The three plants under investigation were reported to use this technique to absorb heavy metal pollutants into their system.

Algae has been recently a plant of interest for biomonitoring eutrophication of organic and inorganic pollutants. Role of algae has been implored in waste water treatment due to its heavy metal cations, based on high negative surface charge. This is an advantage from the viewpoint of tertiary sewage treatment but a disadvantage if the intent is to use waste-grown algae for fish or livestock feeding or composting [14]. Benchraka (2014) reported the use of ten algal spp in Algae Turf Scrubber (ATS) for a period of 21 days for the removal of $\mathrm{Zn}$ and Ni. Zn was $99 \%$ removed [15]. However, Ni wasn't efficiently removed due to the leaching of air stones used for aeration. The work of Giovanni et al, (2012) used five Rp palustis strains (an algal specie) to find out the metal removal capacity of $\mathrm{Ru}$ and $\mathrm{Ru}$ contaminants in solutions. Synechocystis Salina (an algal sp) was also reported to have shown a very good phytoremediating potential for $\mathrm{Cr}, \mathrm{Fe}, \mathrm{Ni}$ and $\mathrm{Hg}$. The plant successfully removed $\mathrm{Cr}, \mathrm{Fe}, \mathrm{Ni}$, and $\mathrm{Hg}$ up to $60 \%, 66 \%$, $70 \%$, and $77 \%$ respectively, in 15 days [5].

Another plant of interest that is used in biotic remediation is Water hyacinth (Eichhornia crassipes). It is a free-floating perennial aquatic plant native to tropical and sub-tropical South America, and is now widespread in all tropic climates [16]. E. crassipes is well known for its enormous biomass production rate, high resistance to pollution, absorption capacity of heavy-metal and nutrient [17]. These properties qualify it for use in wastewater treatment $[17,18]$. A comprehensive overview for Arsenic removal from waste water using E. crassipes. Shows that Up to $600 \mathrm{mg}$ of arsenic was removed from the waste water, and $18 \%$ of the removed arsenic was recovered under laboratory conditions. The report suggested that, the removal efficiency of E. crassipes was due to its high biomass production rate and favourable climatic conditions. Hence, E. crassipes represents a reliable alternative for arsenic bioremediation in aquatic system. However, the plant should be used wisely in phytoremedation, since it may result to severe water management problems due to its huge vegetative reproduction and fast growth rate [19].

Apart from arsenic, the plant can also bio-remediate $\mathrm{Cd}$ and $\mathrm{Cr}$, both $\mathrm{Cd}$ and $\mathrm{Cr}$ where successfully removed to $80.26 \%$ and $71.28 \%$ efficiency, respectively. The average removal rate of $\mathrm{Cr}$ and $\mathrm{Cd}$ per day was $0.10 \mathrm{mg}$ and $0.2 \mathrm{mg}$ respectively [20]. In similar report by Swain et al, (2014), Cu and $\mathrm{Cd}$ where successfully removed by E. crassipes with over $90 \%$ efficiency [21]. The bioconcentration factor of $\mathrm{Cu}$ was higher than that of $\mathrm{Cd}$, showing that the plant is a very good accumulator of $\mathrm{Cu}$.

Pistia stratiotes, often called water cabbage or water lettuce is yet another aquatic plant reported for its bioremediation potential $[22,23]$, metal detoxification, and treatment of urban sewage [24]. Espinosa, (2001) cultured Pistia stratiotes in solutions amended with three different $\mathrm{Pb}$ levels (2ppm, 4ppm and 8ppm) and reported that the bioconcentration factor $(\mathrm{BCF})$ in the plant tissue increases with increase in $\mathrm{Pb}$ level [1]. The report suggested Pistia stratiotes might be useful in $\mathrm{Pb}$ decontamination process in industrial and domestic wastewaters. Thilakar et al, (2012) compared the use of Pistia stratiotes and Salvinia natans in remediating $\mathrm{Cr}$ and $\mathrm{Cu}$ for a period of 10 days in a shaded area [25]. Single metal solution of $25 \%, 50 \%, 75 \%$ and $100 \%$ concentrations of $\mathrm{Cr}$ and $\mathrm{Cu}$ were respectively used. It was noticed that the maximum concentration of $\mathrm{Cr}$ in the $100 \%$ solution was $15657 \mathrm{ppm}$ and $17066 \mathrm{ppm}$ in Pistia and Salvinia respectively, and that of copper was $74.45 \mathrm{ppm}$ and $54.11 \mathrm{ppm}$ respectively. These results indicate that both plants are efficient accumulators of $\mathrm{Cr}$ and $\mathrm{Cu}$, hence both plant can be effectively use to clean up aquatic ecosystem. Prajapati, (2012) used Pistia stratiotes in the removal of $\mathrm{Cr}$ and $\mathrm{Co}$. Both $\mathrm{Cr}$ and $\mathrm{Co}$ were completely removed after $48 \mathrm{hrs}$ of administering the metal solution [12]. However, the removal efficiency of Co in 4 days reduces to $86 \%$ when a mixed solution (i.e binary solution of $\mathrm{Cr}$ and $\mathrm{Co}$ ) is administered to the plant. It was concluded that, both $\mathrm{Cr}$ and $\mathrm{Co}$ can be sustainably removed by Pistia stratiotes. Ugya et al. (2015) has also given an overview for $\mathrm{Hg}, \mathrm{Cd}, \mathrm{Mn}, \mathrm{Ag}, \mathrm{Pb}$ and $\mathrm{Zn}$ removal using Pistia stratiotes in a stream polluted by wastewater from Kaduna refinery and petrochemical company [26].

This current work is done to investigate the bioaccumulative ability of Algae, Eichhornia crassipes (water hyacinth) and Pistia stratiotes (water lettuce) in a multi component metal $(\mathrm{Ni}, \mathrm{Mn}$ and $\mathrm{Pb}$ ) solution system. The research work would aim on quantification the metal uptake by these plants. Hence, waste biomass handling would be reported else were.

\section{Experimental}

\subsection{Preparation of Blank Solutions}

Distilled water $\left(100 \mathrm{~cm}^{3}\right)$ was measured in a sample bottle and treated as sample. Calibration standard was prepared from the stock standard, anticipating the expected concentration in the samples by dilution using a serial dilution formula. 


$$
\begin{array}{r}
\mathrm{C}_{1} \mathrm{~V}_{1}=\mathrm{C}_{2} \mathrm{~V}_{2} \\
\mathrm{~V}_{1}=\mathrm{C}_{2} \mathrm{~V}_{2} / \mathrm{C}_{1}
\end{array}
$$

The amount $\left(\mathrm{V}_{1}\right)$ as calculated using equation 1 , was measured from the stock prepared in volumetric flask $\left(100 \mathrm{~cm}^{3}\right)$ and diluted to $100 \mathrm{~cm}^{3}$ mark with distilled water. Solutions of 2 , $4,6,8$ and $10 \mathrm{ppm}$ were prepared for each metal.

\subsection{Sampling}

The three aquatic plants [alga (Spirogyra sp.), water hyacinth (Eichhornia crassipes), and water lettuce (Pistia stratiotes)] were obtained from Sokoto metropolis (133'5" North, $5^{\circ} 13^{\prime} 53^{\prime \prime}$ 'East), and authenticated by a curator in the Department of Biological Sciences, Usmanu Danfodiyo University, Sokoto. The plant materials were then Washed, collected in a clean plastic container and kept in biological sciences botanical garden for a period of one week to acclimatize with the environmental conditions of the garden [21].

\subsection{Experimental Set up}

The experimental sets up for alga and water lettuce were conducted in a transparent container, while water hyacinth placed into a container of $15 \mathrm{~d} \mathrm{~m}^{3}$ capacity. Metal $(\mathrm{Ni}, \mathrm{Mn}$, and $\mathrm{Pb})$ solutions of three different concentrations $(1,3$, and 5 $\mathrm{mg} / \mathrm{dm}^{3}$ ) were prepared, followed by addition of nutrient in the form of Hoagland solution. The Fourth solution (the control) contained only Hoagland solution. To all the solutions, the $\mathrm{pH}$ was then adjusted to 6 using acetic acid [16].

The different concentration of the metal solutions were administered to the containers containing the plant materials. The weight of the plant materials was taken before and after administering the heavy metal solution. From each of the containers, $50 \mathrm{~cm}^{3}$ of water sample was collected after $24 \mathrm{hrs}$, 5,10 and 15 days of the metal solution administration. Exactly 5 drops of $\mathrm{HNO}_{3}$ acid was added to each of the collected water sample (for proper storage) before AAS analyses [16].

The experiment was conducted for a period of 15 days in a shady area according to the technique reported by Banach et al, (2012). At the end of the $15^{\text {th }}$ day, the plants were harvested, washed and then separated into roots and shoot which were then analysed for metal accumulation using standard techniques [10].

\subsection{Determination of Heavy Metals}

\subsubsection{Sample Treatment}

The plants were harvested on the $15^{\text {th }}$ day and washed with distilled water to remove any adhered substance, it was then separated into shoot and root and then shade dried. The dried shoot and root were grinded, sieved and stored for further use.

\subsubsection{Digestion}

The ashing procedure was done in order to prepare plant samples for elemental analysis [27].

\subsubsection{Wet Digestion}

Air dried grinded sample $(1.00 \mathrm{~g})$ was placed in a beaker, followed by the addition of $\mathrm{HNO}_{3}\left(10 \mathrm{~cm}^{3}, 6 \mathrm{M}\right)$ and $\mathrm{HClO}_{4}$ $\left(2 \mathrm{~cm}^{3}\right)$. Each beaker was covered with a watch glass for an hour to allow the initial reaction to subside. The beakers were heated on a hot plate with the temperature not exceeding $90^{\circ} \mathrm{C}$ for $30 \mathrm{~min}$. The contents were then filtered and transferred into volumetric flask $\left(50 \mathrm{~cm}^{3}\right)$ with subsequent washings and diluted with distilled water to the mark [27].

\subsubsection{Aas Analysis}

The alpha 4 model of Atomic Absorption Spectrophotometer was set according to the manufacturer's instructions with the wavelength corresponding to that of the metal $(\mathrm{Ni}, \mathrm{Mn}$ and $\mathrm{Pb})$ under investigation. Standard solutions prepared from the stock solutions and the blank were used to obtain the calibration curves. The absorbance of each sample was measured in triplicate with an automatic calculation of the average concentration in parts per million (ppm).

\subsubsection{Statistical Analysis}

The analysis was carried out on three independent replicates for every parameter. The results presented in Table 1 are reported as mean \pm standard deviation (SD). Data were analysed by SSPS Anova two ways considering significance at an alpha level of 0.05 .

\section{Results}

The result of heavy metal $(\mathrm{Ni}, \mathrm{Mn}$ and $\mathrm{Pb})$ analysis in different parts of plants under investigation in a multi component metal solution is summarised in Table 1 and represented in Figures 1 to 3. The bioconcentration and transfer factor of the metals are shown in Tables 2 and 3.

\subsection{Nickel Concentration}

The variation in nickel (Ni) concentration in different parts of the aquatic plants under investigation is presented in Figure 1. Nickel concentration increases with increase in concentration of working solution from $1-5 \mathrm{mg} / \mathrm{l}$.

Table 1. Bioaccumulation of Heavy Metal by Different Plant Materials.

\begin{tabular}{lllll}
\hline \multirow{2}{*}{ Plant (mg/kg) } & \multirow{2}{*}{ Concentration (mg/l) } & Heavy Metal & Pb & Mn \\
\cline { 3 - 5 } & & Ni & ND & $305.62 \pm 0.01$ \\
\hline Algae (control) & & ND & ND & $710.54 \pm 0.01$ \\
Water hyacinth (control) & Shoot & ND & ND & $964.17 \pm 0.01$ \\
& Root & ND & ND & $2.39 \pm 0.02$ \\
Water Lettuce (control) & Shoot & ND & ND & $8.21 \pm 0.76$ \\
\hline
\end{tabular}




\begin{tabular}{lllll}
\hline \multirow{2}{*}{ Plant (mg/kg) } & Concentration $(\mathbf{m g} / \mathbf{l})$ & Heavy Metal & Pb & Mn \\
\cline { 3 - 5 } & & $\mathbf{N i}$ & $250.12 \pm 2.94$ & $195.79 \pm 0.02$ \\
Algae & 1 & $10.96 \pm 4.74$ & $292.37 \pm 6.1$ & $388.39 \pm 0.01^{\mathrm{b}}$ \\
& 3 & $79.18 \pm 4.74^{\mathrm{e}}$ & $567.30 \pm 0.1^{\mathrm{a}}$ \\
Water hyacinth Shoot & 5 & $112.76 \pm 2.28^{\mathrm{b}}$ & $539.46 \pm 17.06^{\mathrm{c}}$ & $37.51 \pm .^{13}$ \\
& 1 & $12.11 \pm 0.18$ & $90.09 \pm 0.99$ & $68.37 \pm 1.4$ \\
& 3 & $25.44 \pm 0.83$ & $102.89 \pm 11.41$ & $109.94 \pm 2.76$ \\
Water hyacinth Root & 5 & $28.04 \pm 0.76$ & $413.99 \pm 1.62$ & $0.29 \pm 0.11$ \\
& 1 & $28.04 \pm 0.54$ & $413.99 \pm 7.71$ & $9.7 \pm 1.41$ \\
Water Lettuce Shoot & 3 & $32.67 \pm 1.45$ & $606.03 \pm 7.34^{\mathrm{b}}$ & $32.47 \pm 0.62$ \\
& 5 & $113.89 \pm 3.52^{\mathrm{c}}$ & $737.90 \pm 10.5^{\mathrm{a}}$ & $62.89 \pm 0.2$ \\
Water Lettuce Root & 1 & $5.05 \pm 0.02$ & $0.49 \pm 0.12$ & $85.42 \pm 0.02$ \\
& 3 & $35.69 \pm 0.01$ & $7.98 \pm 2.78$ & $119.86 \pm 0.3$ \\
& 5 & $27.60 \pm 0.01$ & $15.08 \pm 1.43$ & $183.40 \pm 0.02^{\mathrm{e}}$ \\
& 1 & $31.35 \pm 0.01$ & $398.20 \pm 0.1$ & $213.72 \pm 0.1^{\mathrm{d}}$ \\
\end{tabular}

Results are expressed as mean $\pm \mathrm{SD}$.

Values with superscript ${ }^{(\mathrm{a}-\mathrm{e})}$ are the first five best bioaccumulating plant/plant part at alpha 0.05 .

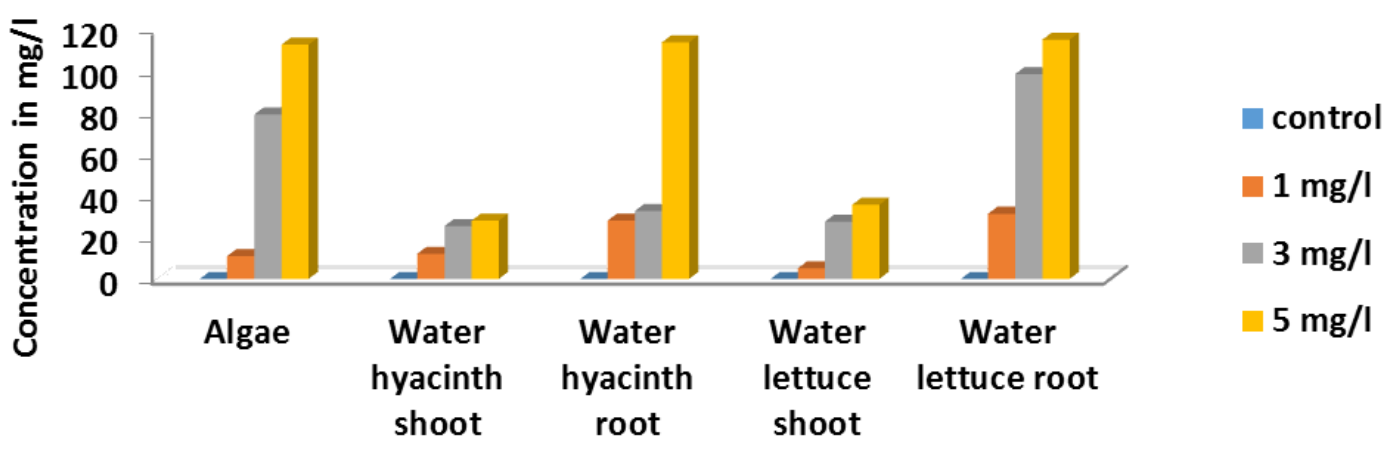

Figure 1. Nickel Concentration in Different Part of Plant Samples.

\subsection{Lead Concentration}

Lead $(\mathrm{Pb})$ concentration increase in the plant sample with an increase in the concentration of the working solution (Figure 2). No lead $(\mathrm{Pb})$ was detected in the control solution.
All the plants were able to accumulate fair amount of the lead $(\mathrm{Pb})$ with water hyacinth root at $5 \mathrm{mg} / \mathrm{l}$ concentration exhibiting the highest accumulation.

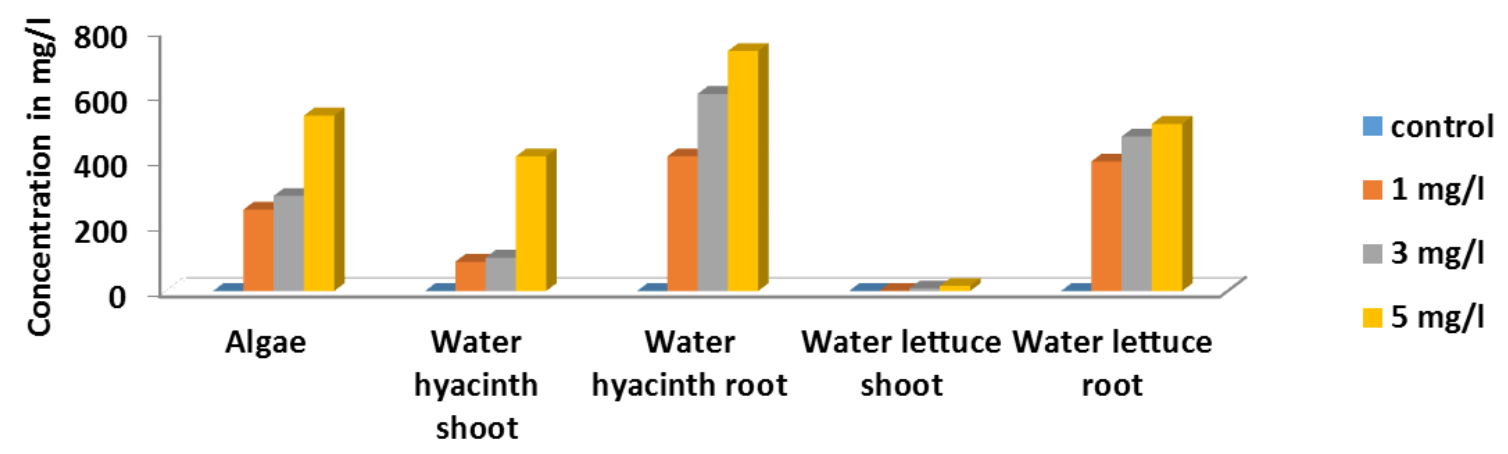

Figure 2. Lead Concentration in Different Part of Plant Samples.

\subsection{Manganese Concentration}

There was considerably large amount of manganese detected in control sample, and pretty good amount was accumulated by all the three plants under investigation. From
Figure 3 below, it can be observed that algae showed the highest accumulation of the metal. Manganese concentration followed similar trend like the previous metals with highest concentration in roots than shoots. 


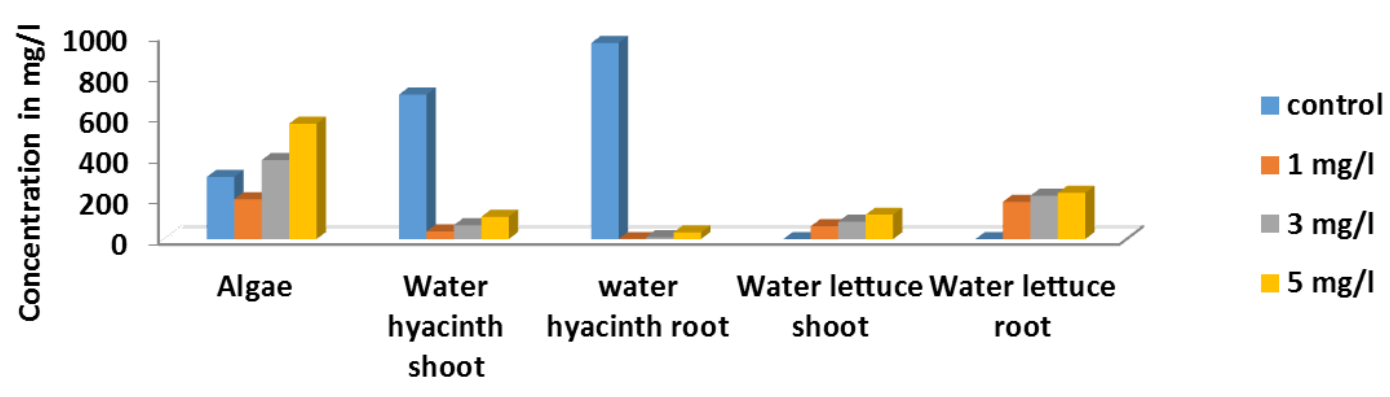

Figure 3. Manganese concentration in different part of plant samples.

\subsection{Bioconcentration Factor}

Bioconcentration factor is a useful parameter for assessing the potential of trace metal accumulation. When metal concentration in water increases, the amount of metal accumulated in plant increases and thus the bioconcentration factor decreases. Bioconcentration factor also provides index of the ability of plant to accumulate metal with respect to the concentration of that metal in the substrate [21]. Results in Table 1 showed that water hyacinth was able to concentrate the $\mathrm{Ni}$, and $\mathrm{Mn}$ relative to $\mathrm{Pb}$, while water lettuce was able to accumulate $\mathrm{Pb}$. Larger value of the bioconcentration factor implies better accumulation capability [16].

Table 2. Bioconcentration factor of Algae, Water hyacinth and Water lettuce.

\begin{tabular}{lllll}
\hline \multirow{2}{*}{ Plant } & Concentration & \multicolumn{3}{l}{ Heavy metals (mg/kg) } \\
\cline { 3 - 5 } & $\mathbf{m g} / \mathbf{l})$ & $\mathbf{N i}$ & $\mathbf{P b}$ & $\mathbf{M n}$ \\
\hline \multirow{3}{*}{ Algae } & 1 & 10.96 & 250.1 & 19.79 \\
& 3 & 26.39 & 97.46 & 129.46 \\
& 5 & 22.55 & 107.89 & 113.46 \\
Water & 1 & 12.11 & 90.09 & 37.51 \\
hyacinth shoot & 3 & 8.48 & 34.30 & 22.79 \\
& 5 & 5.61 & 82.80 & 21.99 \\
Water & 1 & 28.04 & 413.99 & 0.29 \\
hyacinth root & 3 & 10.89 & 202.01 & 3.23 \\
& 5 & 22.79 & 147.58 & 6.49 \\
Water lettuce & 1 & 5.05 & 0.49 & 62.89 \\
shoot & 3 & 11.90 & 2.66 & 28.47 \\
& 5 & 5.52 & 3.02 & 23.97 \\
Water lettuce & 1 & 31.35 & 398.2 & 183.4 \\
root & 3 & 32.88 & 158.30 & 99.71 \\
& 5 & 23.04 & 102.79 & 45.46 \\
\hline
\end{tabular}

Bioconcentration factor $=\mathrm{a} / \mathrm{b}$, where $\mathrm{a}=$ metal concentration in plant and $\mathrm{b}=$ metal concentration in water [21\&26].

\subsection{Transfer Factor}

The Transfer factor (TF) expresses the capacity of a plant to store the metals in its upper part. This is defined as the ratio of metal concentration in the upper part to that in the roots. If $\mathrm{TF}>1$ it indicates that the plant translocates metals effectively from roots to the shoot [28]. Out the three metals on $\mathrm{Mn}$ was effectively translocated. Water hyacinth was able to translocate $\mathrm{Mn}$ according to results in (Table 3). Biotransfer factor shows the ability of the plant to transport metal ion in to the shoot tissues [16].
Table 3. Transfer factor.

\begin{tabular}{lllll}
\hline \multirow{2}{*}{ Plant } & \multirow{2}{*}{$\begin{array}{l}\text { Concentration } \\
(\mathbf{m g} / \mathbf{l})\end{array}$} & \multicolumn{3}{l}{ Heavy metals $(\mathbf{m g} / \mathbf{k g})$} \\
\cline { 3 - 5 } & 1 & $\mathbf{N i}$ & $\mathbf{P b}$ & $\mathbf{M n}$ \\
\hline \multirow{2}{*}{ Water } & 3 & 0.53 & 0.22 & 129.34 \\
hyacinth & 5 & 0.78 & 0.17 & 7.43 \\
& 1 & 0.25 & 0.56 & 3.39 \\
Water & 3 & 0.16 & 0.001 & 0.34 \\
lettuce & 5 & 0.28 & 0.02 & 0.40 \\
& 5 & 0.27 & 0.03 & 0.53 \\
\hline
\end{tabular}

Transfer factor $=\mathrm{c} / \mathrm{d}$, where $\mathrm{c}=$ metal concentration in shoot and $\mathrm{d}=$ metal concentration in root (Liao and Chang, 2004; [26].

\section{Discussion}

\section{Heavy metal accumulation in plants}

As seen in Figure 1 and Table 1, water hyacinth root, water lettuce root and algae shows a very good potential to be used in Nickel decontamination, although it's an essential micro nutrient [20]. The results also revealed that, the plant root has higher affinity for Nickel ion than shoot (Table 1 and Figure 1). This could probably be as a result of some physiological barriers against metal transport i.e due to the inability of the plants to translocate $\mathrm{Ni}$ from the root to the shoot (Table 3). In all the plants, the bioaccumulation of Nickel increases with the increase in the metal concentration (Table 1 and Figure 1). The trend of Nickel accumulation in the different plants can be seen in the following order; water lettuce root $>$ Algae $>$ water hyancith root $>$ water lettuce shoot $>$ water hyancith shoot.

Although Lead concentration was observed to be high in all the plants, water hyancith root showed the highest accumulation; $737.90 \mathrm{mg} / 1$ (Table 1). Like in the case of $\mathrm{Ni}$, the metal accumulation in root is higher compared the shoot (Figure 1). This could be attributed to the avoidance of metal toxicity by the plants, or as a result of greater surface area, hence more adsorption capacity on the roots compared to the shoots $[29,30]$. This could also be as a result of poor translocation factor of the metal from the root to the shoot (Table 3). Algae in $5 \mathrm{mg} / \mathrm{dm}^{3}$ multi metal solution emerged second best accumulator of $\mathrm{Pb}$, and the least accumulation was seen in water lettuce shoot (Figure 2). Therefore, judging from the results obtained in Table 1, water hyacinth root has the highest potential to remove lead $(\mathrm{Pb})$ from waste water followed by Algae. The values obtained are in accordance with the previously reported work, although a 
bit higher [14].

Moderate to low concentration of Manganese was observed in all the plants under investigation. However, a noticeably large amount was recorded in control sample, this could be as a result of its need in physiological activities since it is an essential micro nutrient for plants [20\&31]. Algae recorded highest concentration having $567.30 \mathrm{mg} / \mathrm{l}$, followed by water lettuce with $227.30 \mathrm{mg} / \mathrm{l}$, and the least accumulation in water hyacinth root; $15.08 \mathrm{mg} / 1$. The values obtained for Manganese are in good correlation with previously reported work of Al-Homaidan et al, (2011) [32].

In all the plants, there exists no heavy metal in control sample except manganese (Table 1). Additionally, the heavy metal concentration increases with an increase in the concentration of the multi component metal solution $(5 \mathrm{mg} / \mathrm{l}>$ $3 \mathrm{mg} / \mathrm{l}>1 \mathrm{mg} / \mathrm{l})$. From the statistical analysis, values with different superscript in Table 1 are significantly different from one another, while those with the same superscript are not significantly different down the table for each metal respectively.

Of the metals, Lead has the highest accumulation in the following decreasing order $\mathrm{W}$. $\mathrm{H}$ root $5 \mathrm{ppm}>\mathrm{W}$. H root $3 \mathrm{ppm}>$ Algae $5 \mathrm{ppm}$, followed by Manganese with highest accumulation in algae $5 \mathrm{ppm}>$ algae $3 \mathrm{ppm}>\mathrm{W}$. L $5 \mathrm{ppm}$, and Nickel is the least accumulated, with highest accumulation in Algae $5 \mathrm{ppm}>$ Algae $3 \mathrm{ppm}>\mathrm{W}$. L (W. $\mathrm{H}=$ water hyacinth, W. $\mathrm{L}=$ water lettuce, $\mathrm{ppm}=\mathrm{mg} / \mathrm{l})$. In summary, the accumulation of metals under investigation decreases in the following order; $\mathrm{Pb}>\mathrm{Mn}>\mathrm{Ni}$. Considering the ionic radius and electronegativity of $\mathrm{Pb}$, the priority for its accumulation could be supported, since these factors are believed to influence metal absorption in certain ways.

There was high absorption level in all the three plants for all the metals, this signifies that the plants under investigation can serves as good remediating tool. A surplus advantage that increases their value in phytoremediation, is their ability to accumulate more than one metal at a time.

\section{Conclusion}

In conclusion, studying the phytoremediating potentials of algae, water hyacinth and water lettuce revealed that all the plants were able to accumulate fair amount of lead $(\mathrm{Pb})$ and nickel with water hyacinth root exhibiting the highest accumulation. Algae accumulated highest amount of manganese. Hence, the plants under investigation has proven to be good accumulators of $\mathrm{Ni}, \mathrm{Pb}$ and $\mathrm{Mn}$, and therefore, providing a sustainable and environmentally friendly way of $\mathrm{Ni}, \mathrm{Pb}$ and $\mathrm{Mn}$ removal from waste water. The highest metal accumulation properties shown by water hyacinth and water lettuce is attributed to their large body mass and their rooted nature, which favoured their rhizopheric activity and enhances metal uptake.

\section{Acknowledgements}

The research team wishes to thanks Professor U. A.
Birnin-Yauri of the Department of Pure and Applied Chemistry, Usmanu Danfodiyo University Sokoto, Nigeria for his guidance and support toward the success of this research work.

\section{References}

[1] Espinosa, R. S, (2001). "Lead Uptake and Growth Responses in Pistia Stratiotes Linn. (Quiapo)". The Manila Journal of science, Vol. 4. No. 1.

[2] Kaplan, D, (2013). "Absorption and adsorption of heavy metals by microalgae", Handbook of Microalgal Culture: Applied Phycology and Biotechnology $2^{\text {nd }}$ edition John Wiley \& Sons, Ltd. Blackwell Publishing Limited.

[3] Thayaparan M, Iqbal S. S, Chatburanga P. K. D, Iqbal M. C. M (2013) "Rhizofiltration of $\mathrm{Pb}$ by Azolla pinnata" International journal of environmental sciences, Vol. 3, No 6.

[4] Vardanyan, L. G, and Ingole, B. S, (2006) "Studies on Heavy Metal Accumulation in Aquatic Macrophytes from Sevan (Armenia) and Carambolim (India) lake systems". Environment. International 32, 208-218.

[5] Worku, A, Sahu, O, (2014). "Reduction of Heavy Metal and Hardness from Ground Water by algae" Journal of Applied and Environmental Microbiology, Vol. 2, No. 3, 86-89.

[6] Okafor, E. C, Opuene, K, (2007). "Preliminary Assessment of Trace Metals and Polycyclic Aromatic Hydrocarbons in Sediments" International Journal Enviromental Science Technology. Vol. 4, Pp 233.

[7] Mohiuddin, K. M, Zakir, H. M, Otomo, K, Sharmin, S, Shikazono, N, (2010), "Geochemical distribution of trace metal pollutants in water and sediments of downstream of an urban river" Internaional. Journal. Environmental Science Technology. 7, 17.

[8] Volesky, B, (2000). "Detoxification of Metal Bearing Effluents: Biosorption for the Next Century" Hydrometarllugy, 59, 203-216.

[9] Singh, D, Archana, T, and Richa G, (2012). "Phytoremediation of Lead from Waste Water Using Aquatic Plants" Journal of Agricultural Technology. Vol. 8 (1): 1-11. ISSN 1686-9141.

[10] Banach, A. M, Banach, K, and Stepniewska, Z, (2012) Phytoremediation as a Promising Technology for Water and Soil Purification; Azolla Carolliana Wild. as a case study. Acta Agro Physica 19 (2), 241-252.

[11] Sood, A, Perm, L, Uniyal, R. P, Amrik, S. A, (2012) "Phytoremediation Potential of Aquatic Macrophyte Azolla". AMBIO 41, 122-137.

[12] Prajapati, S. K, Meravi, N, and Singh, S, (2012) "Phytoremediation of Chromium and Cobalt using Pistia Stratiotes: ASustainable Approach" proceedings of the international Academy of Ecology and Environmental Sciences, 2 (2), 136-138.

[13] Jadia D, C, and Fulekar, M. H, (2009). "Phytoremediation of Heavy Metals: Recent Techniques". African Journal of Biotechnology, 8 (6), 921-928. 
[14] Chmielewska, E, and Jad, M, (2001) "Bioaccumulation of Heavy Metals by Green Algae Cladophora Glomerata in a Refinery Sewage Lagoon, CROATIA". CHEMICA ACTA CCACCA 74 (1) 135-145.

[15] Benchraka, C, (2014) "The Role of Algae in Heavy Metals Removal from Mining Wastewater", Thesis Tempere University of Applied Science.

[16] John, G. R, (2007) "Zinc and Chromium Removal Mechanisms from Industrial Waste Water by using Water Hyacinth, Eicchornia Crasssipes" a Thesis Submitted toNational University of Rwanda, memoir online.

[17] Ebel, M, Evangelou, M. W. H, Schaeffer, A, (2007). "Cyanide Phytoremediation by Water Hyacinths (Eichhornia Crassipes)". Chemosphere 66, 816-823.

[18] Fang, Y. Y, Yang, X. E, Chang, H. Q, Pu, P. M, Ding, X. F, Rengel, Z, (2007). "Phytoremediation of Nitrogen-Polluted Water using Water Hyacinth". Journal Plant Nutrient. 30, 1753-1765.

[19] Giraldo, E, Garzon, A, (2002). The Potential for Water Hyacinth to Improve the Quality of Bagota River Water in the Muna Reservoir; Comparison with the Performance of Waste Stabilisation Ponds. Water Science Technology 45 (1), 103 110

[20] Narain, S, Ojha, C. S. P, Mishra, S. K, Chambe, V. C, Sharma, P. K, (2011). Cd and $\mathrm{Cr}$ removal by Aquatic Plant. International journal of environmental sciences. Vol 1, No 6.

[21] Swain, G, Adhikari, S, Moharty, P, (2014). "Phytoremediation of Copper and Cadmium from Water using water Hyacinth (Eicchornia crassipes)" International Journal of Agricultural science and Technology, Vol 2.

[22] Odjegba, V. J, Fasidi, I. O, (2004). "Accumulation of Trace Elements by Pistia Stratiotes: Implications for phytoremediation". Ecotoxicology 13, 637-646.

[23] Skinner, K, Wright, N, Porter-Goff, E, (2007). "Mercury Uptake and Accumulation by Four Species of Aquatic Plants". Environmental Pollution. 145, 234-237.

[24] Zimmels, Y, Kirzhner, F, Malkovskkaja, A, (2006). "Application of Eicchornia Crassipes and Pistia Stratiotes for
Treatment of Urban and Sewage in Israel". Journal Environmental Management 81, 420-428.

[25] Thilakar, R, Pillai, P, (2012) "Phytoaccumulation of Chromium and copper by Pistia stratiotes L. and Salvinia natans (L)" Journal of Natural Product and Plant resources. 725-730.

[26] Ugya, A. Y, Tijjani, S. I and Salisu, M. T, (2015). "The use of Pistia Stratiotes to Remove some Heavy Metals from Romi Stream: A case of Kaduna Refinery and petrochemical company polluted Stream", IOSR Journal of Environmental Science, Toxicology and Food Technology (IOSR-JESTFT) Vol. 9 Issue 1 Ver. II Pp48-51.

[27] Miroslav, R,. and Vladimir, N. B, (1999). "Practical Environmental Analysis". Published by The Royal Society of Chemistry, Thomas Graham House, Science Park. Milton Road Cambridge.

[28] Chakroun, H. K, Souissi, F, Bouchardon, J, Souissi, R, Moutte, J, Faure, O, Remon, E, and Abdeljaoued, S, (2010) "Transfer and Accumulation of Lead, Zinc, Cadmium and Copper in Plants Growing in Abandoned Mining-District Area" African Journal of Environmental Science and Technology. Vol. 4 (10) Pp 651-659. ISSN 1991-637X.

[29] Briat, J. F, Lebrun, M, (1999), "Plant Responses to Metal Toxicity", Plant Biol. Pathol. 322 43-54.

[30] Irfan. S, (2015). "Phytoremediation of Heavy Metals using Macrophyte Culture". Journal of International Scientific Publications, Ecology \& Safety, Vol. 9. ISSN 1314-7234.

[31] Pedas, P, Hebbern, C. A, Schjoerring, J. K, Holm, P. E, and Husted, S, (2005). "Differential Capacity for High- Affinity Manganese uptake Contributes to Differences Between Barley Genotypes in Telorance to low Maganese Availability”. Plant Physiol, 139, 1411-1420.

[32] Al- Homaidan, A, Abdullahi, A, Al- Ghanayem, A, and Alkhalifa, A. H, (2011) "Green Algae as Bioindicators of Heavy Metal Pollution in Wadi Hanifah Stream, Riyadh, Saudi Arabia" International Journal of Resources and Arid Environments. 1 (1), 10-15, ISSBN 2079-7079. 